\title{
THE MIDDLE KINGDOM EGYPTIAN POTTERY FROM MIDDLE BRONZE AGE IIaTEL IFSHAR
}

By Ezra S. M arcus, ${ }^{1}$ Yosef Porath, ${ }^{1,2}$ Robert Schiestl, ${ }^{3,4}$ A nne Seiler,${ }^{4}$ and Samuel M. Paley ${ }^{5}$

\section{INTRODUCTION}

The nature and chronology of Egyptian relations with the southern Levant during the Middle Kingdom (MK)/ Middle Bronze Age IIa (MB IIa) has long been a subject of scholarly controversy. O pinions regarding these relations have varied between extremes positing an Egyptian empire or hegemony over the latter (ALBRIGHT 1928) to a complete negation of any substantial contact (WEINSTEIN 1975), with more moderate characterizations suggesting merely regular diplomatic and economic relations (Posener 1971, 547; WARD 1961; GeRSTENBLITH 1983, 18-21). More recently, the existence of such economic relations has found increased support within a context of burgeoning maritime trade between the Delta and the eastern Mediterranean (e.g., MARCUS 1991; 1998; 2002; 2007; Bietak 1996; Stager 2001; 2002; Cohen 2002, 128-134). While the extreme minimalist position that denies any relations can hardly be held by even its original proponent ( cf. WEINSTEIN 1992), up until recently, the paucity of securely stratified MK Egyptian imports in the southern Levant has meant that the chronology of these relations has been dominated by scarab seal studies (Ben-Tor 1997; 1998b; 2003; 2004; 2007). These analyses conclude that significant Egyptian - southern Levantine relations only began towards the end of the MB IIa - MB IIb transition, which occurred during the Thirteenth Dynasty. H owever, the discovery of more than forty late $12^{\text {th }}$ - early 13th Dynasty Egyptian clay sealings and MK pottery from Phase 14/ 13 (mid-to-late MB IIa) Ashkelon (StAGER 2002, fig. 22; 2008, 1578, 1581, table; BIETAK, KOPETZKY and STAGER, in print), suggests that noteworthy relations began earlier (cf. BEN-TOR 2007, 117-119). The present work will demonstrate that the antiquity of these relations should be taken back even further in light of the presence of MK Egyptian pottery from both

\footnotetext{
Recanati Institute for Maritime Studies, University of Haifa, Israel.

2 Israel Antiquities Authority.
}

Upper and Lower Egypt in the incipient phases of the early MB Il a settlement at Tel Ifshar ( see MARCUS, PoRATH and PALEY, forthcoming). This salient find offers a profound opportunity to reassess and synchronize Egyptian - southern Levantine relations at the dawn of the Middle Bronze Age.

\section{Previous research and discussion of the MK EgYPTIAN POTTERY FROM TEL IFSHAR}

Although a nearly pristine MK Marl A bottle was discovered in 1982 (Paley, Porath and Stieglitz 1982, 260), it was not until after additional sherds were found in the following excavation season that MK pottery in the MB Ila strata at Tel Ifshar was first reported (Paley, Porath and Stieglitz 1983, 266). An illustration of this vessel first appeared three years later (BRAUnsteIn and PALEY 1986, 7). Subsequently, its stratigraphic and, therefore, relative chronological position was briefly described by the excavators, who assigned it, previously, to either Phase B or the succeeding Phase C (PALEY and Porath 1997, 373) or merely Phase C (Paley and Porath 1993, 612); a possible Phase E assignment was also considered (MARCUs 2003, 98-99, based on pers. comm.; see discussion below). In addition, sherds of a similar ware were reported to have originated in dumps of Phases B and C (PALEY and PoRATH 1993, 612; 1997, 373).

No comprehensive study of the entire assemblage has been carried out until now. Indeed, the complete vessel from Tel I fshar is the only MK vessel for which an illustration has been previously published and for which a date has been discussed based on Egyptian pottery typology. Dorothea Arnold is quoted as suggesting a date in the first half of the 19th century BC (BIETAK 1989, 96; 1991, 54). Weinstein cites her as further refining this date to shortly before Sen wosret II (WEINSTEIN 1992, 34-35), i.e., in effect, late Amenemhet II, however, she is mostly quoted as providing a

\footnotetext{
Seminar für Ägyptologie, Freie Universität Berlin. SCIEM 2000, Vienna.

Department of Classics, SU NY Buffalo.
} 


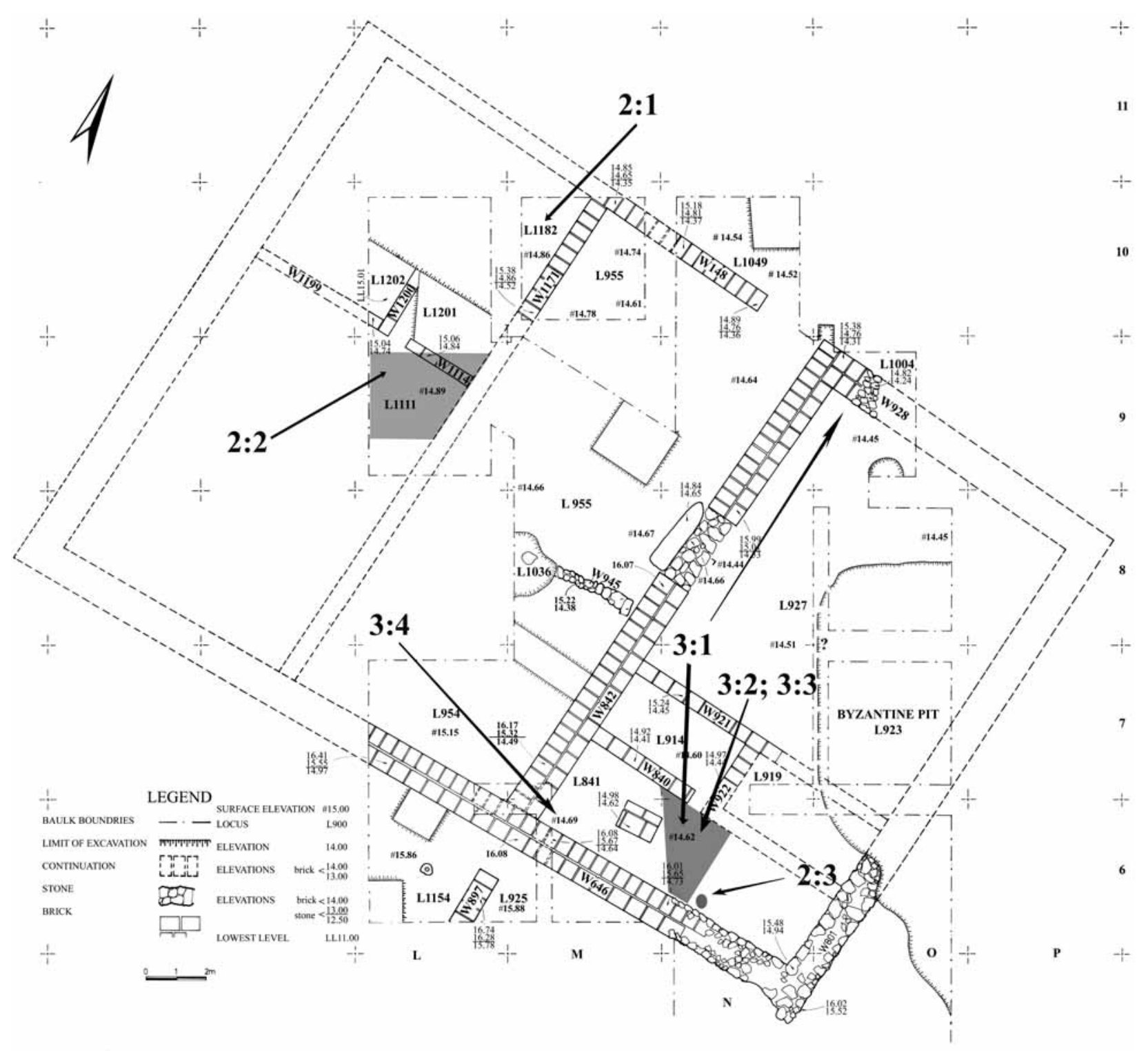

Fig. 1 The location of the loci containing Middle Kingdom pottery from within the Area $\mathrm{C}$ building complex placed on the backdrop of the Phase B plan. Number labels refer to pottery from Figures 2 (Phase A) and 3 (Phase B). Shaded areas indicate where the location of the sherds can be more precisely defined

date range of "Senwosret II- III" (as quoted by Paley and Porath 1993, 612 and 1997, 373). Initially, relying solely on photographs, she placed the other sherds in a broad time range from the early $11^{\text {th }}$ to the $13^{\text {th }}$ Dynasties (WEINSTEIN 1992, n. 27). However, in 1995, thirteen sherds from
Areas $C$ and $A$ were exported to the Metropolitan Museum of Art in New York for research. ${ }^{6}$ Seven examples of various Marl A fabrics were described, in addition to some Levantine and NK examples (Susan Allen, pers. comm.) . ${ }^{7}$

Since the initial discovery and relying on the

${ }^{6}$ These were repatriated shortly before the commencement of this project.

7 H owever, no other comparanda or dating was supplied to us, beyond what was quoted in the literature. A sample (JH 552) from a Marl A vessel body sherd (4286/2)

was taken for Neutron Activation Analysis by J. $\mathrm{H}$ untoon, but the results are absent from the publication of MCGOVERN (2000: 28, 172, appendix 3), who took over her project after her untimely death. 
preliminary reports and personal communications with the excavators and D. Arnold, a number of scholars have incorporated this data in their discussions of Egyptian - southern Levantine relations and synchronization (BIETAK 1991:54; 2002, 39, nn. 42-43; WEINSTEIN 1992, 34-35, nn. 26-27; MARCUS 1998, 152-153; 2003, 96-98, 104-105; CoHeN 2002, 83, 129-130). Unfortunately, as is often the case in ongoing excavations and their analysis, preliminary reports often lack crucial details and additional data and understanding can modify the excavator's opinion. Interpretations based on this incomplete information can easily be inaccurate or misrepresentative and result in confusion or contradiction. In the present case, for example, these inaccuracies include: instances where seven rather than eight MB II a strata $(\mathrm{A}-\mathrm{H})$ were cited; only the complete vessel was noted and the existence of fragmentary sherds were either ignored or assigned solely to Phases C \& E or Phases B through $F$ rather than $B$ and $C$ (as was considered the case prior to the current project, see MARCUS, PORATH and PALEY, 2008, and here below).

\section{The CURRent PRoject}

The present research on the MK pottery from Tel Ifshar is a direct result of the initiation of an Israel Science Foundation funded project to study and publish the MBA remains from Tel Ifshar. This project, inter alia, led to a careful examination of all the extant pottery, which resulted in the identification of additional $\mathrm{Marl} \mathrm{A}$ examples and previously undocumented $M K$ fabrics and types, including Lower Egyptian Marl C. It is now clear that not only were D. Arnold and S. Allen not availed of the entire range of Egyptian fabrics, but sherds belonging to those vessels exported for analysis remained behind undetected. More importantly, this new project enabled a detailed stratigraphic analysis of the relevant phases, including those containing MK pottery (MARCUS, PORATH and PALEY, 2008). In the framework of
SCIEM 2000 (BIETAK 2000; BIETAK and KLEINSGÜTL 2000), it was decided to carry out a collaborative effort to study these important finds and include them in the Middle Kingdom Pottery Handbook project. During a weeklong visit by R. Schiestl and A. Seiler in April, 2008, all of the extant pottery baskets were examined; previous identifications were reassessed and additional MK Egyptian pottery was discovered. ${ }^{8}$ During this process, some joins were determined and some restoration was carried out; all of the diagnostic sherds were documented and drawn. In the case of the complete Marl bottle, redrawing confirmed the inaccuracy of the existing published illustration, which erroneously depicts it, inter alia, as a symmetrical vessel (cf. Paley and Porath 1997, fig. 13.5:4 with that presented here).

\section{The Middle Kingdom Egyptian Pottery}

Egyptian Middle Kingdom pottery was found in Area C in three successive MB Ila phases, A, B, C and also possibly Phase $E$. The material is presented and discussed in stratigraphic order (Figures 2-4). The pottery fabrics have been classified according to the "Vienna System" (NORDSTRÖM and BOURRIAU 1993). The largest group consists of pieces made of Marl C (Fig. 2:1, 3; Fig. 3:2-4 and Fig. 4:1). The source for this fabric is generally considered to be located in the MemphisFaiyum region (ARNOLD 1981; NORDSTRÖM and BOURRIAU 1993; BADER 2001; 2002). The other fabrics present belong to the group of Marl clays of Upper Egyptian origin (NORDSTRÖM and BOURRIAU 1993, 177-178): Marl A3 (Fig. 4:2), Marl A4 (Fig. 2:2) and Marl DAN E3 (Fig. 3:1), a fabric not classified in the Vienna System (SeILER 2005, 35). ${ }^{9}$

As was to be expected, pottery made of Nile clay - the predominant fabric used for pottery in all times in Egypt - was not found, nor were there any open vessels in the assemblage. Marl clays are denser, harder and more robust than Nile clays. Closed vessels made of these fabrics are thus better suited for long distance transport.

\footnotetext{
8 New Kingdom pottery was also discovered among the finds from Areas $C$ and $A$, but will not be discussed here. Since this study was carried out more ceramic finds have been located in the IAA storerooms and will be examined in the future.

9 DAN stands for Drac Abu el-Naga/ Thebes, where this clay was first identified by A. Seiler. It is a temporary
}

designation, pending an expansion of the Vienna System. The fabric is very fine and dense. The colour of the break is homogenously red and the surface is a thick, hard white layer. It can be considered a very fine version of Marl B, while it also displays some similarities to $M$ arl A2 (both in the Vienna System). 
The following is a typological discussion of the various shapes, in order to date their occurrences in Egypt as finely as possible. Egyptological studies of MK pottery mostly focus on widely distributed and very common shapes made of Nile clays, such as hemispherical drinking cups and "beerjars". U pper Egyptian Marl clay vessels are particularly scarce and we know much less about their development and thus their dating.

\section{Phase A}

\section{Contexts}

Phase A (the oldest phase) produced three examples, two of which (Fig. 2:1, 2) come from L 1204 and $L 1133$, respectively, each of which represent the leveling, fill or make-up of two Phase $B$ floors, L1182 or L1111 (Fig. 1). The third example (Fig. 2:3) derives from a pit, $L 754$, that cut through another Phase A fill, L 732, and penetrated virgin soil. This pit is sealed by the fill that formed the foundation of a Phase B floor, L841, which was $20-40 \mathrm{~cm}$ above the sherd.

\section{Typological analysis and dating}

Fig. 2:1 (7229/1) shows the rim and shoulder of a jar with a very wide aperture made of $\mathrm{Marl}$ C1. The short everted rim is incurved on the inside. The rim diameter of about $38 \mathrm{~cm}$ is remarkably large, particular when considering the relatively thin wall thickness. It is an unusual piece. No precisely matching example can be cited from Egypt and none of the closest parallels are complete vessels, but based on fragmentary evidence we can gain a rough idea of the shape. Fragments of examples of similar shape were found in the pyramid complex of Senwosret I at Lisht (ARNold 1988, fig. 74:60) and in an early MK settlement at Tell elDabca, area F/ I (CZERny 1999, 189, Mc. 52). Both display a similar shoulder, indicating an only slightly broadening body contour, whose maximum diameter is not much wider than the width of the aperture. The shape can be reconstructed as a cylinder-shaped or slightly bag-shaped jar with a flat base (See CZERny 1999, 92-93, Abb. 41). The rim of the Tell el-Dabca piece dates from the late $11^{\text {th }}$ Dynasty through the reign of Amenemhet I and a single example as late as Senwosret I (ca.
1980-1940 BCE) is, however, distinctly different; the Lisht example shows some degree of similarity. These jars could be considered part of the family of large MK Marl C containers, commonly called zirs ( see below, Phase B, fig. 3:3-4). Rims of zirs can also be slightly incurved, but no example is known where this feature is as pronounced as in the Tel Ifshar piece. Distinctly incurved rims are, however, often found on one type of vessel, which is quite common in the Middle Kingdom: Marl C jars with a short spout (BADER 2001, 152-153, Abb. 41). Again, we do not possess a complete vessel from Egypt, but one was found in a tomb at Kerma (Dunham 1982, 65-66, 252, fig. 113, x1, pl. xxv. c:2), a site that is rich in Egyptian Middle Kingdom ceramic imports (BoURRIAU 2004). This piece is essentially a globular to bag-shaped zir with a slightly incurved rim and a spout attached beneath the rim. The fragmentary spouted jars with incurved rims published by BADER from Tell el-Dabca are set apart from our piece by their markedly smaller apertures and the lack of a shoulder. None date earlier than the late $12^{\text {th }}$ Dynasty. A 13th Dynasty date can be cited for an unpublished example from Karnak-North (JACQUET-GORDON, pers. comm.) ${ }_{10}^{10}$ which shows a similarly large aperture (rim diameter about 34 $\mathrm{cm}$ ) and a pronounced incurved rim, but the body displays no shoulder. The Lisht fragment was found on a transportation road of the pyramid complex of Senwosret I amongst material not directly linked with the construction of the pyramid. Based on stratigraphic and typological criteria ARNold $(1988,124)$ gives a date range from post late Senwosret I to Amenemhet III. However, for most of the material from this area she provides a finer date, namely to the later part of this period, the reigns of Senwosret III-Amenemhet III (ARNOLD 1988, 140-143). To summarize: while this body shape seems to have a long tradition, starting in the early $12^{\text {th }}$ Dynasty and continuing until at least into the second half of this Dynasty and most likely lasting to its end, the best parallels known for the rim shape are relatively late, starting in the second half of the $12^{\text {th }}$ Dynasty, with stronger evidence for the late $12^{\text {th }}$ and $13^{\text {th }}$ Dynasty. A fine dating based on Egyptian comparative material clearly eludes us.

\footnotetext{
$\overline{10}$ We are very grateful to $\mathrm{H}$. Jacquet-Gordon for providing us with her unpublished study on the pottery from KarnakNorth.
} 


\begin{tabular}{|c|c|c|c|}
\hline Tel Ifshar & $\mathrm{Squ}$ & $/ 10$, L1204 & $7229 / 1$ \\
\hline \multicolumn{2}{|c|}{ Marl C1; plain } & \multicolumn{2}{|l|}{ Phase A } \\
\hline \multicolumn{4}{|c|}{ SChiesti/SEILER } \\
\hline
\end{tabular}
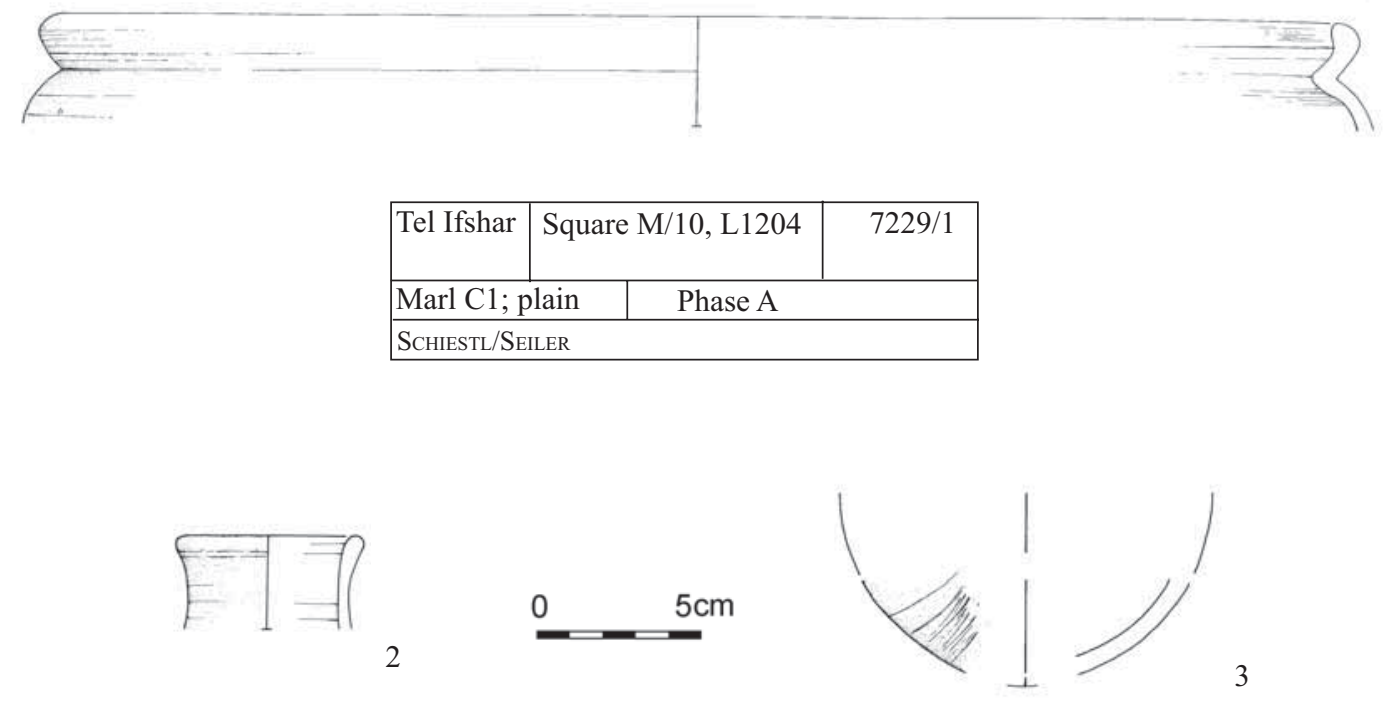

\begin{tabular}{|c|c|c|c|}
\hline Tel Ifshar & \multicolumn{2}{|c|}{ Square L/9, L 1133} & $5986 / 1$ \\
\hline Marl A4; & & Phase A & \\
\hline
\end{tabular}

\begin{tabular}{|c|c|c|c|}
\hline Tel Ifshar & \multicolumn{2}{|c|}{ Square N/6, L 754} & $4568 / 1$ \\
\hline Marl C2; & & Phase A & \\
\hline
\end{tabular}

Fig. 2 Middle Kingdom Egyptian pottery from Phase A

The second piece from Phase A (5986/ 1, Fig. $2: 2$ ) is the rim and neck of a bottle made of Marl A4. While very similar to the neck of the complete vessel shown on fig. 4:2, it is slightly wider and shorter. It is impossible to reconstruct how the body looked. The neck has links to both the tradition represented by the complete bottle (i.e., late Amenemhet II-Senwosret III) and to the late phase of the tradition preceding it (Amenemhet II). ${ }^{11}$ This earlier shape group consists of roundbased, globular bottles, such as have been found in the U pper Egyptian cemetery of El-Kab ( $\mathrm{SCHI}$ ESTL and SEILER, in prep.), ${ }^{12}$ which have similar necks.

Fig. 2:3 (4568/1) is a body sherd from a small globular made of sandy Marl C (i.e., Marl C2) jar. It belongs to a jar of the same size as the rim shown on Fig. 3:2, and they could have formed one piece. However, while the body sherd is attributed to Phase $A$, the rim was found in Phase
$B$, where the jar type is discussed in detail. In the absence of a rim, no date can be offered, apart from the basic date range for this jar, namely late Senwosret I - Amenemhet III (see detailed discussion below).

\section{Phase B}

\section{Contexts}

The mudbrick building complex founded in Phase B produced the largest quantity of MK pottery at Tel Ifshar (minimum four and a maximum of 7 vessels). Figs. 3:1-4 and one (4296/4) of two body sherds, which are not illustrated here, were found in a room near the southeastern corner of the building (Fig. 1). ${ }^{13}$ The base of Fig. 3:1, Fig. 3:2, Fig. $3: 3$ and 4296/ 4 derive from L 841 and were all found in the debris accumulation 15-40 $\mathrm{cm}$ above the room's floor in an area of approximately $2.5 \mathrm{~m}^{2}$. In contrast, Fig. 3:4 was found

11 For a detailed treatment of these traditions, see below for the discussion of the bottle.

12 E.g., Berlin 14036 from tomb 121 and Manchester Museum 3247 from tomb 156.

13 These are both Marl A fabrics and similar in appearance, but do not join with any of the other pottery. The second piece (4424/1) comes from a disturbed context near a Byzantine pit. 

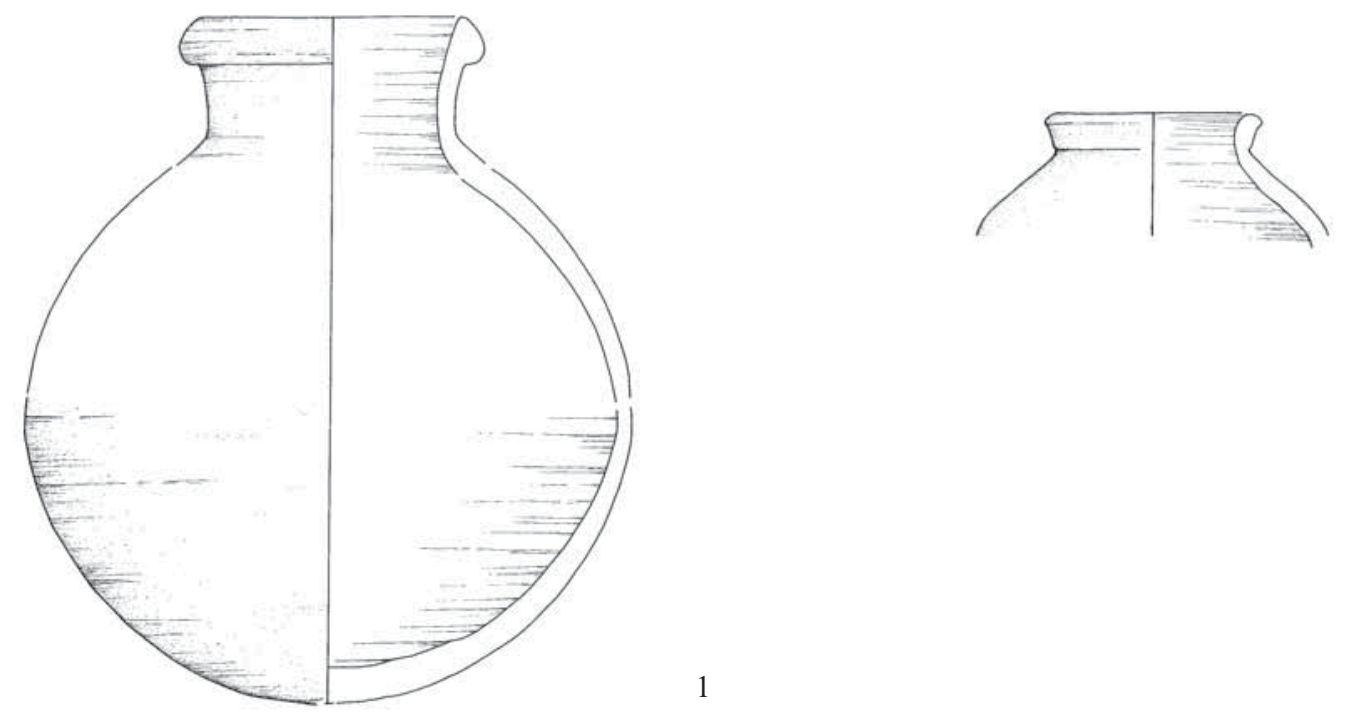

\begin{tabular}{|l|l|l|}
\hline \multirow{3}{*}{ Tel Ifshar } & Rim: Square O/9, L 927 and surface & $5071 / 1,4398 / 1$ \\
\cline { 2 - 4 } & $\begin{array}{l}\text { Base: Squares N/6, O/7; L 841, } \\
\text { surface/Byzantine pit }\end{array}$ & $\begin{array}{l}4286 / 2,4431 / 1, \\
4451 / 1\end{array}$ \\
\cline { 2 - 3 } & $\begin{array}{l}\text { Body, no join: Square M/4, L 741 } \\
4456 / 1-2\end{array}$ \\
\hline Marl DAN E3; plain burnished & Phase B \\
\hline SCHIESTL/SEILER
\end{tabular}

\begin{tabular}{|c|c|c|c|}
\hline Tel Ifshar & \multicolumn{2}{|c|}{ Square N/6, L 841} & $4313 / 1$ \\
\hline Marl C2; p & & Phase B & \\
\hline
\end{tabular}

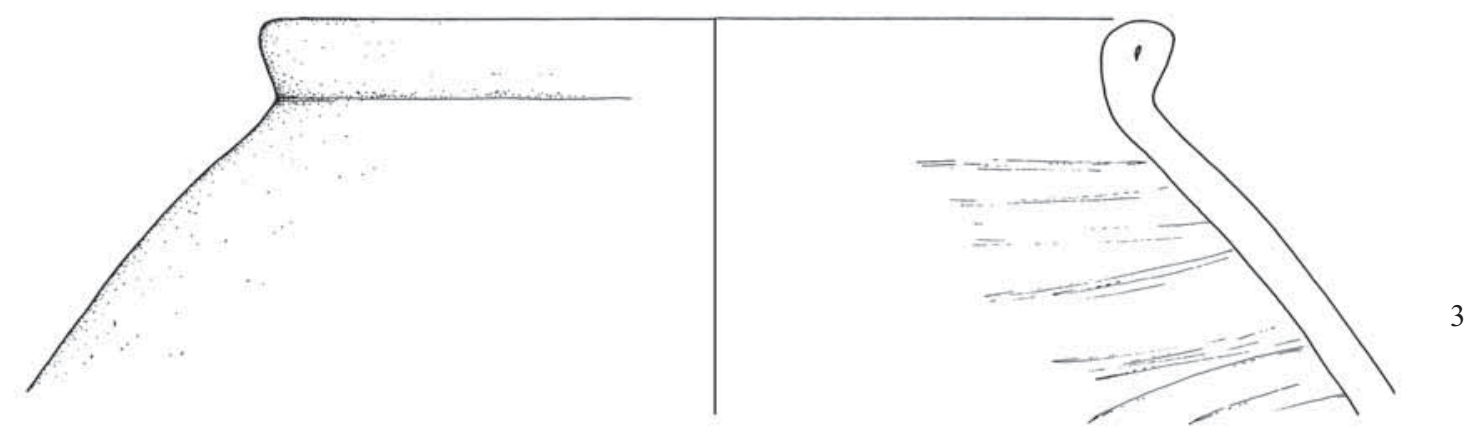

\begin{tabular}{|c|c|c|c|}
\hline Tel Ifshar & \multicolumn{2}{|c|}{ Square N/6, L 841} & \multirow[t]{2}{*}{$4511 / 3$} \\
\hline \multicolumn{2}{|c|}{ Marl C1; plain } & Phase B & \\
\hline \multicolumn{4}{|c|}{ SCHIESTL/SEILER } \\
\hline
\end{tabular}

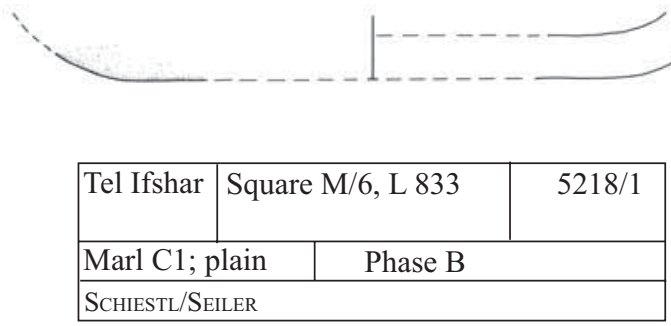

4

Fig. 3 Middle Kingdom Egyptian pottery from Phase B 
0.54-1.00 $\mathrm{m}$ above the floor, below the roof and brick collapse of Phase B and could have derived from part of the roof. Part of the rim of Fig. 3:1 was found some $10 \mathrm{~cm}$ above the floor, L927, near the corner of a large room some $14-18 \mathrm{~m}$ to the north of L841. Thus, either of these two contemporary loci could be the original context of this vessel. The remaining sherds from this reconstructed vessel (Fig. 3:1) derive from later contexts or the area south of the building, i.e., Phase $C$ or Byzantine pits. As no complete vessels were found in Phase $B$, it might be argued that some of the sherds originally derive from Phase $A$ and were used in construction. However, such a large concentration of individual vessels in one fairly well defined area in the southeastern wing of the building, L927 and, especially, L841, lends more credence to these deriving from vessels damaged in the destruction of Phase $B$, where they may have been placed somewhat higher than floor level (e.g., on shelves, furniture, etc.). Some sherds from these vessels ultimately became residual already during the leveling and reconstruction that heralded the subsequent Phase $C$ building. This process of ceramic upwelling continued during the Byzantine Period, when the digging of pits on the eastern side of the building caused the most profound disturbance in the location of the fragmentary MK pottery, which may explain why most of the vessels could not be fully restored.

\section{Typological analysis and dating}

A globular jar, with a short, slightly everted neck and a modelled rim could be reconstructed from numerous sherds (Fig. 3:1). As there is no join between upper and lower part, there might actually be two vessels of this ware. ${ }^{14} \mathrm{H}$ owever, as type, size, fabric and surface treatment are, as far as can be ascertained, identical for all sherds, the parts are illustrated together to form one vessel. The reconstructed height of the jar is $21 \mathrm{~cm}$. It is made of Marl DAN E3 clay and the plain, cream colored surface of the jar is burnished. While the surface of this piece is today weathered, similarly treated examples still display a lustrous exterior, usually cream colored, pink or reddish. The shape and the surface treatment suggest an inspiration from stone vessels. Only a few close parallels are known from Egypt, such as from El-Kab ${ }^{15}$ and Thebes ${ }^{16}$ (SCHIESTL and SEILER, forthc.). However, this sort of jar is frequently found exported outside of Egypt: numerous similar examples are known from Nubian cemetery sites such as Tushka, Adindan and Aniba. The largest assemblage of typologically very similar vessels has been unearthed at Kerma (BOURRIAU 2004) and recently an example from Sidon has been published (ForSTNERMüLLER and KOPETZKY 2006). The Kerma jars were found in tombs dating from Kerma Moyen I (roughly equalling the early $12^{\text {th }}$ Dynasty) to Kerma Moyen VI (early 13th Dynasty), suggesting, prima facie, a long running type. However, this chronological range is backed neither by the Egyptian evidence, nor by the Nubian contexts. Based on rather scant evidence, it seems that burnished Upper Egyptian Marl jars in Egypt are restricted to the first half of the $12^{\text {th }}$ Dynasty. They appear with a globular or ellipsoid body shape and have modelled rims of various shapes: disc-shaped, triangular or with a thickened rim, which is sort of sickle-shaped in section (CZERNY 1998, fig. 18). The latter type is only associated with an ellipsoid body shape and is found in layers at Tell el-Dabca dated approximately to the reign of Amenemhet II. A few fragments have also appeared in later layers in Egyptian contexts - whether they were from old jars which had remained in use for a long period of time or whether they are evidence of a continued small scale production cannot be said with certainty. The long circulation at Kerma is a sign of the enduring popularity and prestige of these jars, as is also signalled by an example of which the neck had broken off and which was meticulously mended (BOURRIAU 2004, fig. 11:2). The Egyptian evidence points towards an end in production by the mid $12^{\text {th }}$ Dynasty, but the Kerma pieces indicate that such jars might have been in circulation for an extremely long time period, possibly up to 200 years.

Fig. 3:2 is the rim and shoulder of a small Marl C2 jar (4313/1), most likely of globular body shape. A graphic reconstruction of the jar resulted in a height of about $12 \mathrm{~cm}$. The body sherd discussed above (Fig. 2:3) formed part of a vessel of

\footnotetext{
$\overline{14}$ In addition, the body sherds (4456/ 1-2) join with neither upper nor lower part, so theoretically there could have been three vessels.
}

\footnotetext{
15 Petrie Museum of Egyptian Archaeology, UC 18372, from tomb 34.

16 Drac Abu el-Naga, ZN 04/ 176.
} 
the same basic type, but due to the lack of a join and the nature of the find spots it may not be part of the same vessel. Small globular Marl C jars are produced in Egypt from the later part of the reign of Senwosret I (Lisht, ARNOLD 1988, fig. 74; Elephantine, von PILGRIM 1996,160 f) until the reign of Amenemhet III (Tell el-Dabca). ${ }^{17}$ They are equipped either with small round shaped rims or, as is the case here, with slightly elongated modelled rims, which are marked by a fine ledge in the upper part of the rim and a ledge at the bottom of the rim, where the body begins. While all well dated early, and some later, examples display the round shaped rim, none of those with the elongated ledge rim has a secure date. However, the same rim type appears with slightly larger globular examples and in particular with the very common bag-shaped examples (Fig. 4:1 is to be reconstructed as the latter). All securely dated examples of the former fall into the reign of Amenemhet III and the early $13^{\text {th }}$ Dynasty (e.g., Dahshur; ARNold 1982, fig. 19:1) and the bagshaped jars, clearly an evolution from the globular jar, start in the reign of Amenemhet III and continue, with such a modelled rim, until at least the mid-13th Dynasty (BADER 2001, 108-122). In short, while there is good evidence for the body shape from the late reign of Senwosret I onwards, the only certain dates for this rim type - regardless with what body shape it is combined - fall in the period of Amenemhet III or later. It is very possible that this rim type started earlier, but evidence for such a precursor is still lacking.

Fig. 3:3 shows the rim and upper part of a large scale storage jar, which in Egyptology is often called a "zir" (4511/3). These jars are generally wide mouthed and invariably made of $\mathrm{M}$ arl C (BADER 2001, 155-193); most are made of Marl $C 1$, as is the case with this piece. This example has a rim diameter of $26 \mathrm{~cm}$. The complete vessel had a bag-shaped body and was equipped with a flat base. These jars are very frequently found in Egyptian settlement sites, but are also found in tombs. In the course of the Middle Kingdom and the Second Intermediate Period their body and rim shapes develop in chronologically significant ways, however, some types continue being pro- duced for long periods of time. As these vessels are rarely found intact, the typological focus has been on the development of the rim shape. The Tel Ifshar example has a squat rim of a rounded triangular shape. Such rims appear first in the second decade of the reign of Senwosret I (ARNOLD 1988, fig. 59:3) and continue until the first half of the $13^{\text {th }}$ Dynasty (BADER 2001, 163, Abb. 45c). In short, the rim, and the vessel, is unfortunately of no help for fine dating.

The zir is the only large size Egyptian container of this period found in the Levant. Despite their unwieldy appearance and size ${ }^{18}$ such jars were transported over enormous distances, both by land and sea. Large assemblages were found at the mining site of Gebel el-Asr, $65 \mathrm{~km}$ northwest of Abu Simbel (Engelbach 1938, pl. LX:4; SHAW 2000; SHAW et al 2001, fig. 3) and, recently, at Abu Ziyar, along the route from the Nile valley to the Kharga oasis (DARNELL 2006, figs. 3-4). The export of zirs to the Levant, to where they presumably had been transported by ship, is documented at Tell CArqa (KOPETZKY, pers. comm.), Byblos (MONTET 1928, pl. CXXIV; DunAND 1964, pl. II), Sidon (BADER 2003, fig. 4; ForSTner-Müller, KopetZKY and Doumet-Serhal 2006, 54-55, fig. 4) and Ashkelon (Stager 2002, 359, fig. 21; BietAK, KopetZKY and STAGER, in print).

Part of the base of another Marl C1 storage container was also found in Phase B (Fig. 3:4). The base is flat and has a diameter of roughly 16 $\mathrm{cm}$. The small size makes it very unlikely that it belonged to the same jar as Fig. 2:1; rather, it could have belonged to a smaller version of a zir.

\section{Phase C (or earlier)}

\section{Contexts}

Fig. 4:1 derives from the area south of the main building complex and all that can be said at the present stage of the stratigraphic analysis is that it may be assigned to Phase $\mathrm{C}$ at the very latest.

Typological analysis and dating

Fig. 4:1 is made of Marl C1 and most likely formed part of a medium size bag-shaped jar. This type of vessel is equipped with either round

\footnotetext{
17 cEzbet Rush di, Czenny, in prep.; we thank E. Czerny for kindly providing us with the information on the pottery from CEzbet Rushdi.
}

\footnotetext{
$\overline{18}$ For example, the Gebel el-Asr examples have an average capacity of 76.5 liters (SHAw et al. 2001, 34).
} 
rims or with slightly elongated, modelled rims. Two manufacturing techniques can be distinguished: vessels are either handmade in a mould with the rim turned on a turntable or they are wholly made on the potter's wheel (BADER 2002, 39). The Tel Ifshar example was more likely produced in the latter way, although often only the lower - in our case missing - half is handmade. However, this technological classification seems to have no chronological relevance. These medium to small size vessels ( for a detailed discussion see BADER 2001, 108-120) are a very common and widespread shape in Egypt and are found frequently both in tombs and settlements. Their heyday clearly lies in the last third of the $12^{\text {th }}$ Dynasty, from approximately the reign of Amenemhet III, and in the 13th Dynasty. However, it is very likely that they developed from earlier, more globular examples of the first half of the $12^{\text {th }}$ Dynasty (e.g., Elephantine, VON PILGRIM 1996, Abb. 160i; Tell el-Dabca, Bader 2001, Abb. $22 \mathrm{~m}$ ). These examples al ready display a lengthening of the body, in which the center of gravity is starting to shift to the lower half of the vessel. As globular jars remain in fashion until the end of the 12th Dynasty (Dahshur, ARNOLD 1982, fig.
19:1), there is considerable overlap with the bagshaped jars. Unfortunately, evidence is lacking for the development of the latter in the period covered roughly by the reigns of Senwosret II and III. The relatively slender body shape of the piece under discussion is possibly an argument for placing it closer to the later, more bagshaped group than to the earlier more globular examples.

\section{Phase C or E}

\section{Contexts}

The stratigraphic assignment of the complete bottle (Fig. 4:2) remains unresolved and will be the focus of future efforts (CF. MARCUS, PORATH and PALEY, 2008). At present, all that may be said is that no architectural phases earlier than Phase $C$ seem to have been preserved south of the building. The stratigraphic connection between the Phase $C$ and $E$ architecture south of and that of the phasing within the building is problematic and, as such, until the assemblages in the former are studied and compared with the latter, their synchronization will remain unresolved. Such a study is underway, but may not provide conclusive

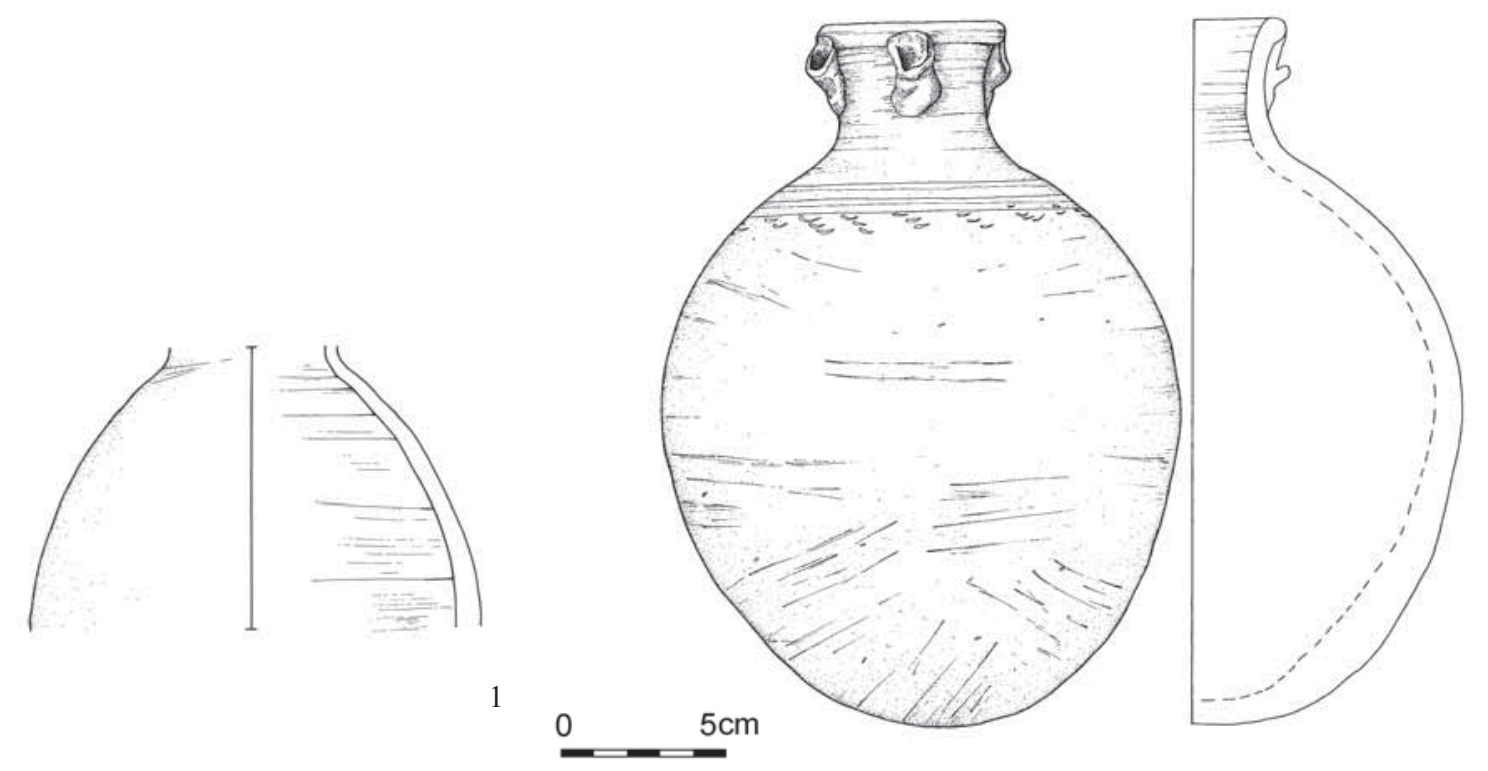

2

\begin{tabular}{|l|l|c|}
\hline Tel Ifshar & $\begin{array}{l}\text { Square M/1, Surface } \\
\text { or possibly L 734 }\end{array}$ & $4454 / 1$ \\
\hline Marl C1; plain & $\leq$ Phase C \\
\hline SCHIESTL/SEILER \\
\hline
\end{tabular}

\begin{tabular}{|l|l|c|}
\hline Tel Ifshar & Square N/4, L 626 & $\begin{array}{c}3627 / 1 \\
\text { IAA 86-637 }\end{array}$ \\
\hline $\begin{array}{l}\text { Marl A3; incised and } \\
\text { applied decoration }\end{array}$ & Phase C or E \\
\hline SCHIESTL/SEILER \\
\hline
\end{tabular}

Fig. 4 Middle Kingdom Egyptian pottery provisionally assigned to Phases C-E (see text above) 
resolution to this issue; clarifying the stratigraphic connection may require additional excavation.

\section{Typological analysis and dating}

The bottle (Fig. 4:2) is made of Marl A3 and has a decoration consisting of clay rolls attached to the vessel's neck beneath the rim and incised lines on the shoulder. When discussing this vessel, two points need to be emphasized: first, very few close parallels in shape, fabric and decoration are known from Egypt; and second, even the best of those parallels are not very well fixed, chronologically. Thus, the two main features of the vessel shape and decoration - need to be discussed separately in more detail.

Shape: The round-based vessel is of a wide ovoid, almost globular shape and is slightly asymmetrical. There is no pronounced shoulder. The lower half of the neck is straight and the upper half slightly everted. Its height of $21.3 \mathrm{~cm}$ makes it is a medium size container by MK Egyptian standards. Both larger and smaller versions of very similarly shaped and decorated U pper Egyptian Marl bottles can be cited from the U pper Egyptian cemetery of El-Kab (Q UIBELL 1898, pl. XVI, 53, 70). Possibly these pieces can be identified with bottles currently stored in the Petrie Museum, University College London, and the Penn Museum, Museum of Archaeology and Anthropology, Philadelphia. ${ }^{19}$ However, these bottles are from tombs whose contexts are incomplete and which had been used for multiple burials and possibly later reuse. Thus, they offer little help in dating. Therefore, the Ifshar vessel can only be placed in the general development of such bottles. The following sequence is suggested: the shape under discussion is preceded by a range of globular and ellipsoid shaped jars and bottles, whose necks are shorter and wider (the tradition during the period of Amenemhet I - Amenemhet II, or roughly the first half of the 12th Dynasty). Examples can be cited from Upper Egypt at Elephantine (VON PILGRIM 1996, Abb. 157 a), El-Kab (SCHIESTL and SEILER, in prep.), Thebes (ARNOLD 1991, fig. 58) and Mostagedda (BRUNTON 1937, pl. LXVIII, 14-15); and from Lower Egypt at Tell el-Dabca, CEzbet Rushdi, Str. e/ 4 ( M ), from the time of Amenemhet II (CZerny 1998, fig. 17); as well as from Kerma
(BOURRIAU 2004, fig. 6:1). These shape groups are followed, al beit with allowance for a degree of overlap, by a more ovoid shape, with a slightly longer and narrower neck, as in the case of the Tel Ifshar bottle. The time span for this shape group is late Amenemhet II - Senwosret III. By the last third of the 12th Dynasty (later Senwosret III through the end of the Dynasty) these bottles seem to have disappeared, at least judging by the Lower Egyptian evidence, while for Upper Egypt the picture is patchier. Large Nile clay bottles with characteristically shaped necks and rims, generally called beerbottles, are by then the predominant type.

Decoration: The bottle is decorated with four small rolls of clay attached to the upper part of the neck, just beneath the rim, and an incised decoration on the shoulder. The latter decoration consists of a band of 5 fine horizontal lines, beneath which small oblique rows of short irregular lines or crescents are impressed at roughly equal distance. The same five-pronged instrument, a comb or a fishbone, was used for both incised designs. Such decoration is typical for Upper Egypt, where it has a long tradition and is added to various types of open and closed vessels. Considering solely the decorative features on bottles examples may be cited ranging from the reign of Senwosret I (Thebes, tomb of Senet; De Garis-Davies and Gardiner 1920, pl. $X X X I X)$ through the later 12th Dynasty (Elephantine, RZEUSKA 1999, Abb. 45:7) to the 13th Dynasty (Askut, SMITH, in prep., fig. 10h). Generally, finely executed and more elaborate decorations, consisting of multiple parallel lines and often involving rhombus shaped elements, are typical for the early Middle Kingdom (e.g., El-Kab, QuIBeLL 1898, pl. XVI, 59; Dendera, MARCHAND 2004, fig. 109, pl. 4; Karnak North, Jacquet-Gordon, pers. comm.). In the Second Intermediate Period, decorations reemerge on a large scale, but in a simpler and cruder fashion. Less frequently very simple incised and applied decorations can be observed for the late $12^{\text {th }}$ and early $13^{\text {th }}$ Dynasty (Abydos, WEGNER 2007, fig. 115:130; El-Kab, QUIBELL 1898, pl. XIV:1; Askut, SMITH, in prep.). It becomes clear that the Upper Egyptian decorative tradition of incised and applied designs continued throughout the Middle Kingdom. In this still incomplete picture of the decorative development, the Tel Ifshar bottle

\footnotetext{
${ }_{19}$ E.g., UC 18356 from tomb 84 and Philadelphia E 2332 from tomb E 218. The pieces will be published by SCHIESTL/ SEILER, forthc.
} 
would be best placed between the "early elaborate" group of the early $12^{\text {th }}$ Dynasty and the "late simple" tradition starting in the late $12^{\text {th }}$ Dynasty.

So, taking all these factors - body shape, length and width of neck, design, overall size into consideration, this bottle was most likely produced in the time span between the later years of Amenemhet II and the reign of Senwosret III (about 1890-1850 B.C.), as Dorothea Arnold has al ready suggested. As the vessel remains complete to this day, it has satisfactorily proven its durability. A long life of use, and later deposition, is thus entirely feasible, although not a certainty or a necessity, given the still unclear nature of its context at Tel Ifshar.

\section{Discussion}

\section{The chronological implications of the Middle Kingdom pottery from Tel Ifshar}

A number of chronological implications emerge from the presence of MK pottery in MB Ila levels at Tel Ifshar, both in relative and absolute terms. First, its occurrence in early MB Ila levels, principally Phases $A-C$, which are characterized by the so-called Levantine Painted Ware, is unique in the southern Levant. The only other assemblage of MK pottery reported in the region is from the Moat Deposit at Ashkelon and that is dated to a more advanced stage of the MB Ila period (StAger 2002; 2008, 1578, 1581, table; BIETAK, KOPETZKY and STAGER, in print), which is probably to be synchronized with Ifshar Phase $E$ at the earliest. At present, the only known parallel in the Levant for the juxtaposition of MK pottery with Levantine Painted Wares occurs at Sidon, where Phase 1 produced a single Marl $\mathrm{C}$ goblet and Phase 2 produced six examples, including two complete vessels, one each of $\mathrm{Marl} C$ and $\mathrm{Marl} A$ (BAder 2003; Doumet-Serhal 2008, 17-22). However, the precise synchronization of Sidon with Tel I fshar must await further analysis.

In the current state of research, for many of the formsfound at Tel Ifshar, only broad chronological brackets may be proffered within the $12^{\text {th }}$ and, for some very long-lived types, the $13^{\text {th }}$ Dynasties. $\mathrm{Nev}$ ertheless, a number of salient observations can be made. Those forms for which slightly shorter peri- ods of production and use are defined, e.g., Fig. 2:2 in Phase $A$ and Fig. 3:1 in Phase B, suggest a time frame in the first half of the $12^{\text {th }}$ Dynasty, from Amenemhet II to Senwosret III. While this evidence cannot provide a terminus post quem for the founding of Phase $A$, it does suggest that the transition to Phase B, i.e., the founding of Phase $B$, occurred sometime within this period. A lower bracket for the destruction of Phase $B$ is less refined, although the end of production in the mid-12th Dynasty of the type represented by Fig. $3: 1$, is a reasonable working hypothesis. H owever, the rim type of Fig. 3:2, which is best paralleled from Amenemhet III into the 13th Dynasty, might lower this date somewhat.

These dating limitations do not preclude a comparison with radiocarbon determinations from Tel Ifshar (MARCUs 2003). The calendrical range of combined identical samples from multiple laboratories of single year cultigens from Phase B suggest a time frame between 1920 and 1770 BCE (MARCUS 2003, 104-106, fig. 6). ${ }^{20}$ Similarly, the calendrical range of combined samples from Locus 626, a context immediately below the complete Marl A3 bottle, offers a time frame of 1890 to 1730 BCE (M ARCUs 2003, 104-106, figs. 4, 5 and 7). Clearly, these calibrated ranges for the early settlement phases strongly correlate with the historical date ranges of the Egyptian pottery.

To summarize, in relative terms, MK pottery makes its first appearance in the southern Levant already in the incipient phase(s) of the Middle Bronze Age Ila. In Egyptian historical terms this period appears to be coeval with the mid-12th Dynasty, sometime in the reigns of Amenemhet II, Senwosret II and Senwosret III (ca. 1911-1850 $B C E$ ). This historical range is supported by radiocarbon determinations from Tel Ifshar.

\section{A one-off occurrence or the tip of a southern Levantine iceberg? The Middle Kingdom pottery from Tel Ifshar in its wider context}

In total, a minimum of eight and a maximum of 12 individual MK vessels have been identified at MB II a Tel Ifshar. These represent the largest assemblage of MK pottery so far discovered in the southern Levant and possibly the largest in the entire Levant from such an early phase of the MB IIa period..$^{21}$ Their

\footnotetext{
$\overline{20}$ Note that a single radiocarbon determination from L 752 (M ARCus 2003, table 5, fig. 5) might offer a slightly higher upper bound for Phase A.
} 
association with the earliest MB Ila levels at this site and possibly with the earliest phase of MB Ila culture in the region begs the central question as to whether this assemblage is indeed unique or actually part of a wider phenomenon. In the long history of Egyptian - Levantine relations, both unique, exclusive and significant expressions of contact (e.g, Old Kingdom/ Early Bronze Age II-III \& MK/ MB II Byblos) and broad distributions of Egyptian artifacts are not unknown (e.g., Naqada II-III/ Early Bronze $\mathrm{Ib}$ and New Kingdom/ Late Bronze southern Levant). Which pattern fits the evidence from Tel Ifshar can only be properly considered within the broader regional context of such relations.

Over three decades ago, Weinstein (1975) published a seminal article on the interactions between Egypt and the southern Levant during the Middle Kingdom in which he rejected any substantial contacts or relations. Rather, he saw all evidence of contact with Egypt as having been mediated largely via Lebanon and Syria (WEINSTEIN 1975, 7-9, 12, fig. 3). The impact of this model on research was profound and can be discerned in many syntheses and general publications on this period (e.g., Gerstenblith 1983, 19-21; BEN-TOR 2007), although a number of works do not follow the more extreme views of his thesis (e.g., MARCUS 1991, 39-45; 1998; 2002; BietaK 1996; ILAN 1995; Stager 2001; 2002).

A full critique of Weinstein's model is beyond the scope of this work, and might not seem relevant after the time that has passed since its publication, the fact that his work continues to be cited as authoritative (BEN-TOR 2006, 78-80; BEN-TOR 2007, passim), and does not seem to have allowed for the subsequent discoveries from Ashkelon and Ifshar, warrants some explanation. First, Weinstein developed his basic thesis at a time when the length and the true urban nature of MB II culture were still largely misconstrued, and some still saw it as a transitional phase between the semi-nomadic Middle Bronze I/ Intermediate Bronze Age to the true urban Middle Bronze Age IIb (WEINSTEIN $1975,13)$. Thus, his preconception regarding the potential for Egyptian interest in the southern Levant. Second, the majority of those MK finds he does discuss are in the coastal plain and Megiddo, the heartland of MB IIa settlement and culture, where one would expect a larger data set; many of those sites where he notes meager or no MK finds (e.g., Beth Shean, Jericho, Safed, and sites in the Central Highlands) are in areas on the periphery of MB Ila culture, many of which were not settled until fairly late in the period, or in the transition to the Middle Bronze Age IIb. The lack of such a regional distinction in his assessment did not allow for an accurate gauging of the potential for new relevant evidence being found in the Coastal Plain. Third, in treating Egyptian - southern Levantine trade in isolation, Weinstein ignores the rhythms and complexities of eastern Mediterranean MB IIa maritime trade, which brought the southern Levant into contact with additional regions such as Cyprus and the Aegean (DeVER 1976, n. 104; ARTZY and Marcus 1992; Stager 2002; KisleV, Artzy and MARCUS 1993). The absence of Egyptian finds at any particular site might just as well reflect the degree to which any site, even in the Coastal Plain, interacted with these seaborne networks. Such specialization may explain why, for example, a central site like Tel Aphek, lacks M B II a Cypriot imports, in contrast to the contemporary inland harbor downriver at Tel Gerisa (Geva 1982, 36-37, fig. 32).

Last, and most important, the absence of Egyptian imports at those sites in the Coastal Plain that had been excavated by 1975, e.g., Aphek, could indeed be attributed partly to selective excavation (cf. WEINSTEIN 1975, 7). However, it is also possible that excavators' selective or limited knowledge of Egyptian ceramic fabrics had significant impact. However, during the last few decades greater international collaborative between archaeologists working in Egypt and Israel, including projects such as SCIEM 2000 and its Stratigraphie Comparée Program (BIETAK and KLEINSGÜTL 2000; BIETAK, Ko PETZKY and StAGER, in print), has greatly enhanced the opportunity for expert identification of MK Egyptian pottery.22

\footnotetext{
${ }^{21}$ StAger $(2002,359)$ reports 6 zir sherds in Phase 14 and the Moat Deposit. The largest MK assemblages are from Sidon, where in addition to the aforementioned examples, 19 fragments were found in Phase 3 and 51 fragments in Phase 4, which are assigned, respectively, to the third phase of the MB Ila and the transitional MB IIa/ II b (Doumet-Serhal 2006, 39; 2008, 22-23).
}

\footnotetext{
${ }^{22}$ Note also the significant contribution of such collaborations to the study of the finds at Sidon (FORSTNERMüLler, Kopetzky and Doumet-Serhal 2006). A similar impact on the study of Egyptian - Levantine relations in the Early Bronze has been noted by LEVY and VAN DEN BRInk $(2002,3)$.
} 
Although petrographic studies have become much more commonly applied to issues relating to the Middle Bronze Age (COHEN-WeINBERGER and Goren 2004; Cohen-Weinberger 2007), systematic fabric study of ceramic assemblages are largely non-existent and it is not beyond the realm of possibility that imported body sherds, including MK pottery, may have been discarded during pottery reading and sorting. No Egyptologist with the requisite familiarity with Egyptian pottery bothered to comb through the voluminous baskets of pottery excavated in the southern Levant in hope of identifying possible Egyptian imports. Indeed, the giant conceptual shadow cast by Weinstein's 1975 article may have discouraged archaeologists working in Israel for looking more actively and carefully for Egyptian pottery. If the current project has taught us anything, methodologically, it has demonstrated the need to afford special ists the opportunity for first hand access to the material. ${ }^{23}$ While Marl A fabrics were noted at Ifshar during the excavation al ready in the 1980s, it was only during the past year that $\mathrm{Marl} C$ wares were even identified, let alone systematically sought for among the finds.

Regarding the selective presence of MK pottery and selective excavation, the limited spatial distribution of these wares at Tel Ifshar is instructive and may indicate why its discovery is so rare. At Tel Ifshar, Egyptian pottery is concentrated in a very small area of the MB II a remains exposed in Area $C$; no MK pottery was found in the limited exposure of $M B$ lla remains in Area $A$. As noted above, the majority of the Phase $B$ MK pottery is localized in an area of approximately $2.5 \mathrm{~m}^{2}$. In total, only 11 out of 50 , or $22 \%$ of the excavation squares contained at least a single sherd of MK pottery. Thus, there is less than a 1in -5 chance of choosing a square to excavate that will produce MK pottery. Similarly, despite much more extensive excavation than at Tel Ifshar, MK Egyptian pottery and scarab sealings were found only in the Moat Deposit at Ashkelon. Perhaps such a spatially restrictive distribution is to be expected. A wider intrasite distribution of Egyptian pottery or its presence in mortuary contexts might be more indicative of a cultural affinity, which in the Middle Bronze Age only happens, as in the widespread use of scarabs, through the influence of the Canaanite/ Hyksos presence/ kingdom in the Delta (Ben-Tor 2007, 2). Middle Kingdom pottery is, however, found in contemporary burials at Sidon and later in Byblos (TUfNeLL 1969, 16, nos. 59, 60), the latter where Egyptian cultural influence has always been presumed to have been widespread.

Indeed, the crux of Weinstein's argument, and that of others, regarding Egyptian - southern Levantine relations rests on the perceived difference between the distribution of Egyptian artifacts in Byblos and the southern Levant (1975, 11-12; cf. BEN-T OR 2007, 117-119). While Byblos has traditionally been considered the perennial partner harbor for Egypt, recent studies of the Annals of Amenemhet II from Mit Rahina (MARCus 2007) and the Khnumhotep III inscription from Dahshur (James P. Allen, inter alia, lecture given at the Hebrew University, Jerusalem, 5 March 2008) suggest that MK Egyptian relations with Byblos only resumed in the mid-12th Dynasty, during the reign of Senwosret III. Prior to this development, Egypt seems to have had maritime relations with Ulassa (Tripoli?), from which cedar was imported, and with regions further to the north (Allen, ibid.; MARcus 2007). Indeed, the Montet Jar remains the earliest well-stratified and dated assemblage of MK artifacts at Byblos, principally scarabs of the early MK series, which begins in the early $12^{\text {th }}$ Dynasty, but continued in use until sometime in the reign of Senwosret III, if not later (BEN-Tor 1998a, 12; 2004; 2007, 5, 185 ). Apparently, the southern Levant seems to have had demonstrable contacts with Egypt at least as early as Byblos, if not earlier, as evidenced by the MK finds from Tel Ifshar and the imported Levantine storage jars from the Carmel Coast and southwestern Negev identified at CEzbet Rushdi (COHENWeInBerger and Goren 2004, 80-81, 92, table 1; Marcus 2007, 162, 165-167). These are complemented by the aforementioned finds from Sidon. Thus, the monolithic Byblio-centric paradigm for characterizing relations between Egypt in the Levant is in need of revision. Contacts between Egypt and the southern Levant in the first half of the $12^{\text {th }}$ Dynasty must be considered a fundamental

\footnotetext{
${ }^{23}$ During their visit to $\mathrm{H}$ aifa, Robert Schiestl and Anne Seiler also identified an MK sherd from Akko. It will be published in a separate study.
} 
reality in any treatment of these relations (contra BEN-TOR 2007 and BEN-TOR 2006). ${ }^{24}$

The MK finds from Tel Ifshar appear to be part of mid $12^{\text {th }}$ Dynasty Egyptian - Levantine relations. Why such finds should be found at a site situated $5 \mathrm{~km}$ from the sea al beit up a navigable river is unclear, although the MK finds do appear to fit a pattern represented by other contemporary finds found there with a northern Levant origin or inspiration (MARCUS, PORATH and Paley 2008). What relationship may exist between these finds, maritime trade and the settlement and development of this site are issues to be considered elsewhere.

\section{CONCLUSIONS}

The MK pottery from early MB Ila Tel Ifshar includes imports from Upper and Lower Egypt in well stratified settlement layers that represent the beginning of the site's and possibly the region's MBA sequence. Clearly, these finds demonstrate that more significant contacts existed between the southern Levant and Egypt than have previously been considered. These contacts apparently are part of a pattern of complex maritime relations between Egypt, the southern and northern Levant. This interaction demonstrates the importance of integrating all types of material cultural and historical evidence in seeking to understand cultural, economic and, potentially, political relations. The role of Tel Ifshar in this pattern is far from clear and whether its significance is a result of location, resources, or human agency still needs to be explored. In any event, the finds from Tel Ifshar, as well as those from Ashkelon, should challenge excavators to make a more concerted effort to pay attention to the possibility and degree of contact with Egypt during the Middle Bronze Age IIa. If indeed the MK pottery from Tel Ifshar is not a one-off occurrence, but merely the tip of an iceberg, then like the metaphor, presumably most of the mass of this phenomenon still remains below the surface.

\section{Acknowledgements}

This research was supported by the Israel Science Foundation's Legacy Fund (Grant No.
1113/ 06) and is part of a project entitled: "Tel Ifshar: the earliest Middle Bronze Age Ila settlement of the coastal plain of Israel and its relations to Egypt and the northern Levant", in which $E$. Marcus is the principal investigator in collaboration with Y. Porath. They are aided by a team of research assistants: P. Waiman-Barak, A. Golan, A. Efron and N. Bogomolov. Thanks to the staff of the Recanati Institute for Maritime Studies for all of their help, especiallyJ. Gotlieb, the Institute conservator. Figure 1 was prepared by $P$. Waiman- Barak based on original architectural plans by Y. Porath, E. Baranes and A. Snyder. J. Ben-Michael of the IAA was of crucial assistance in recovering artifacts from the Beth Shemesh storage facility as was G. Litani from the National Treasures storeroom. N. Agha of the IAA Artifacts Treatment Department for kindly provided details on the export and repatriation of some of the MK pottery. The visit of R. Schiestl and A. Seiler to the University of $\mathrm{H}$ aifa was funded by SCIEM2000, who also support E. Marcus's work. They all express their sincerest appreciation to M. Bietak and the SCIEM 2000 staff, especially, D. Melman and A. Schwab. The excavation of Tel Ifshar was a major component of the Emeq $\mathrm{H}$ efer Archaeological Research Project, directed by S.M. Paley, Y. Porath and R. Stieglitz, under the auspices of the State U niversity of N ew York at Buffalo and the I srael Department of Antiquities and Museums, now the Israel Antiquities Authority (IAA). O ther participating and supporting institutions included The Brooklyn Museum, The Jewish Museum (New York), Rutgers University - N ewark, Adelphi University (Garden City, NY), the College of DuPage (Glenn Ellyn, Illinois). As noted, some of the finds discussed here were previously studied by D. Arnold and S. Allen of the Metropolitan Museum of Art in New York. We appreciate their expert advice and suggestions, but they bear no responsibility for the views expressed above. These finds were repatriated and couriered to the IAA in Jerusalem by D. Ben-Tor. We thank her for shlepping these sherds back and ultimately making this research possible.

\footnotetext{
${ }^{24}$ Tel Ifshar and the preliminary reports of its MK pottery are suprisingly absent from D. Ben-Tor's seminal work. Similarly, A. Ben-Tor ignores the evidence from both
}

Ifshar and Ashkelon in his assessment of Egyptian Levantine relations. 


\section{Bibliography}

Albright, W. F.

1928 The Egyptian Empire in Asia in the Twenty-First Century B.C., Journal of the Palestine O riental Society 8:223-256.

ARnold, D.

1981 Ägyptische Mergeltone ("Wüstentone") und die Herkunft einer Mergeltonware des Mittleren Reiches aus der Gegend von Memphis, 167-191, in: D. ARnold (ed.), Studien zur altägyptischen Keramik, Mainz.

1982 Keramikbearbeitung in Dahschur 1976-1981, M DAIK 38:25-65.

1988 Pottery, 106-146, in: D. ArNoLD, The Pyramid of Sen wosret I, The South Cemeteries of Lisht I, Publications of the M etropolitan M useum of Art Egyptian Expedition 22, N ew York.

1991 Amenemhet I and the early Twelfth Dynasty at Thebes, M etropolitan M useum Journal 26:5-48.

ARTZY, M., and MARCUS, E.

1992 Stratified Cypriote Pottery in MBIla Context at Tel Nami, 103-110, in: G. IoAnNides (ed.), Studies in $\mathrm{H}$ on or of Vassos Karageorghis, Nicosia.

BADER, B.

2001 Tell el-Dabca XIII. Typologie und Chronologie der $M$ ergel $C$-K eramik. M aterialien zum Binnenhandel des $M$ ittleren Reiches und der zweiten Zwischenzeit, UZK 19, Vienna.

2002 A Concise Guide to Marl C-Pottery, E\& L 12:29-54.

2003 The Egyptian Jars from Sidon in their Egyptian Context, AHL 18:31-37.

BEN-TOR, A.

2006 Do the Execretion Texts Reflect an Accurate Picture of the Contemporary Settlement Map of Palestine?, 63-87, in: Y. AMIT, E. BEN ZVI, I. FINKELSTEIN, and O. LIPSCHITS (ed.), Essays on Ancient Israel in Its Near Eastern Context: A Tribute to Nadav Na'aman, Winona Lake, Indiana.

BEN-TOR, D.

1997 The Relations between Egypt and Palestine in the Middle Kingdom as Reflected by Contemporary Canaanite Scarabs, IEJ 47:162-189.

1998a The Absolute Date of the Montet Jar Scarabs, 1-17, in: L. H. LESKo (ed.), Ancient Egyptian and Mediterranean Studies in Memory of William A. Ward,. Providence.

1998b The Relations Between Egypt and Palestine During the Middle Kingdom as Reflected by Contemporary Canaanite Scarabs, 149-163, in: C. J. EYRE (ed.), Proceedings of the Seventh International Congress of Egyptologists, Cambridge, 3-9 September 1995, OLA 82, Leuven.

2003 Egyptian-Levantine Relations and Chronology in the Middle Bronze Age: Scarab Research,
239-248, in: M. BIETAK (ed.), The Synchronization of Civilisations in the Eastern M editerranean in the Secand Millennium B.C. II, Proceedings of the SCIEM 2000 - Euro Conference, $\mathrm{H}$ aindorf $2^{\text {nd }}$ of $\mathrm{M}$ ay $-7^{\text {th }}$ of M ay 2001, CChEM 4, Vienna.

2004 The Political Implications of the Early Scarab Series in Palestine, 1-6, in: A. NunN and R. Schulz (ed.), Skarabäen außerhalb Ägyptens: L okale Produktion oder Import? Workshop an der LudwigM aximilians-U niversität, M ünchen, N ovember 1999, BAR IS 1205, Oxford.

2007 Scarabs, Chronology, and Interconnections: Egypt and Palestine in the Second Intermediate Period. OBO SA 27, Fribourg.

BIETAK, $M$.

1989 The Middle Bronze Age of the Levant - a New Approach to Relative and Absolute Chronology, 78-120, in: P. Åström (ed.), High M iddle or Low? Acts of an international colloquium on absolute chronology held at the U niversity of Gothenberg, 20-22 August 1987, Part 3, Gothenberg.

1996 Avaris: The Capital of the $H$ yksos. Recent Excavations at Tell el-Dabca, The first Raymond and Beverly Sackler Foundation distinguished lecture in Egyptology, London.

1991 Egypt and Canaan During the Middle Bronze Age, BASOR 281:27-72.

2002 Relative and Absolute Chronology of the Middle Bronze Age: Comments on the Present State of Research, 30-42, in: M. BIETAK (ed.), The Middle Bronze Age in the Levant, Proceedings of an international conference on M B IIA ceramic material, Vienna, $24^{\text {th }}-26^{\text {th }}$ of January 2001, CChEM 3, Vienna.

Bietak, M. (ed.)

2000 The Synchronisation of Civilizations in the Eastern $M$ editerranean in the Second M illennium BC. Proceedings of an international symposium at Schloß $\mathrm{H}$ aindorf, $15^{\text {th }}-17^{\text {th }}$ of N ovember 1996 and at the A ustrian Academy, Vienna, $11^{\text {th }}-12^{\text {th }}$ of May 1998, CChEM 1, Vienna.

BietAK, M. and KLEINSGÜTL, D.

2000 The Synchronization of Civilizations in the Eastern Mediterranean in the $2^{\text {nd }}$ Millennium $B C$, 99-102, in: P. Matthiae, A. Enea, L. Peyronel, and F. PInNoCK (ed.) Proceedings of the First International Congress on the Archaeology of the Ancient N ear East, Rome, M ay $18^{\text {th }}-23^{\text {rd }} 1998$, vol. 1, Roma.

Bietak, M., Kopetzky, K. and Stager, L.

in print Stratigraphie Comparée Nouvelle: The Synchronisation of Ashkelon and Tell el-Dabca, in: Procedings of the Third ICAANE 2002, Paris.

BOURRIAU, J.

2004 Egyptian Pottery Found in Kerma Ancien, Kerma Moyen and Kerma Classique Graves at Kerma, 3-13, in: T. Kendall (ed.), Nubian Studies 1998, Proceedings of the $\mathrm{N}$ inth Conference of the International 
Society of Nubian Studies, August 21-26, 1998, Boston, M assachu setts, Boston.

Braunstein, S.L. and Paley, S.M.

1986 Among Ancient Empires. Excavation Catalogue, October 27, 1986, The Jewish Museum, New York.

BRUNTON, G.

1937 M ostagedda and theTasian Culture, BME 1, London. COHEN, S.L.

2002 Canaanites, Chronologies, and Connections: the Relationship of M iddle Bronze Age Ila Canaan to Middle Kingdom Egypt. Studies in the Archaeology and $\mathrm{H}$ istory of the Levant - SAHL 3. Cambridge, Ma.

Cohen-Weinberger, A.

2007 Petrography of M iddle Bronze Age 2 Pottery: Implications to Understanding Egypto-Canaanite Relations, unpublished doctoral dissertation, Tel Aviv University.

Cohen-Weinberger, A., and Goren, Y.

2004 Levantine-Egyptian Interactions During the $12^{\text {th }}$ to $15^{\text {th }}$ Dynasties Based on the Petrography of the Canaanite Pottery from Tell el-Dabca, E\& L 14:69-100.

Czerny, E.

1999 Tell el Dabca IX. EinePlansiedlung des frühen M ittleren Reiches, UZK 15, Vienna.

1998 Zur Keramik von CEzbet Rushdi (Stand Mai 1997), E\& L 8:41-46.

DARNELL, J.C.

2006 Abu Ziyar and Tundaba, Yale Egyptological Institute in Egypt, www.yale.edu/ egyptology/ ae_tunda ba_remains.htm

DEVER, W.G.

1976 The Beginning of the Middle Bronze Age in SyriaPalestine, 3-38, in: F. Cross, W. LemKe and P. MILLER, JR (eds.), Magnalia Dei, the Mighty Acts of God: Essays on the Bibleand A rchaeology in M emory of G. Ernest Wright. Garden City, New York.

Doumet-Serhal, C.

2006 Sidon: Mediterranean contacts in the Early and Middle Bronze Age, preliminary report, $\mathrm{AHL}$ 24:34-47.

2008 The British Museum Excavation at Sidon: M arkers for Chronology of the Early and Middle Bronze Age in Lebanon, 11-44, in: M. BIETAK and E. Czerny (ed.), The Bronze Age in the L ebanon: Studies on the Archaeology and Chronology of L ebanon, Syria and Egypt, CChEM 17, Vienna.

DunAND, M.

1964 Rapport Préliminaire sur les Fouilles de Byblos en 1962, BM B 17:29-35.

DUNHAM, D.

1982 Excavations in Kerma, Part VI, Boston.

ENGELBACH, R.

1938 The Quarries of the Western Nubian Desert and the Ancient Road to Tushka, ASAE 38:369-390.
Forstner-MüLLER, I. and KOPETZKY, K.

2006 An U pper Egyptian I mport at Sidon, AH L 24:60-62.

Forstner-Müller, I., Kopetzky, K., and Doumet-Serhal, C.

2006 Egyptian Pottery of the Late $12^{\text {th }}$ and $13^{\text {th }}$ Dynasty from Sidon, AH L 24:52-59.

De Garis-Davies, N. and Gardiner, A.

1920 The Tomb of Antefoker, Vizier of Sesostris I, and of $\mathrm{H}$ is Wife Senet (No. 60), Theban Tomb Series 2, London.

Gerstenblith, P.

1983 The L evant at the B eginning of the M iddle Bronze Age, American Schools of O riental Research Dissertation Series, no. 5, Winona Lake, In.

Geva, S.

1982 Tell Jerishe: The Sukenik Excavations of the Middle Bronze Age Fortifications, Q edem 15, Jerusalem.

ILAN, D.

2005 The Dawn of Internationalism - the Middle Bronze Age, 297-319, in: T.E. Levy (ed.), The Archaeology of Society in the H oly Land, London.

Kislev, M., Artzy, M., and Marcus, E.S.

1993 Import of Aegean Food Plant to a Middle Bronze II A Coastal Site in Israel, L evant 25:145-54.

LEVY, T.E., and VAN DEN BRINK, E.C.M.

2002 Interaction Models, Egypt and the Levantine Periphery, 3-38, in: E.C.M. VAN DEN BRINK and T.E. LEVY (eds.) , Egypt and the Levant: Interrelations from the Fourth Through the Third Millennia BCE, London.

MCGOVERn, P.E.

2000 The Foreign Relations of the "H yksos": A Neutron Activation Stu dy of M iddleB ronze A ge Pottery from the Eastern Mediterranean. With a contribution by Tine Bagh, BAR IS 888. Oxford.

MARCHAND, S.

2004 Fouilles récentes dans la zone urbaine de Dendera: La céramique de la fin de l'Ancien Empire au début de la XIIe dynastie, CCE 7:211-238.

MARCUS, E.S.

1991 Tel Nami: A Study of a Middle Bronze IIA Period Coastal Settlement, Unpublished master's thesis. University of $\mathrm{H}$ aifa.

1998 M aritime Trade in the Southern L evant from Earliest Times through the M B Ila Period, Dissertation submitted to Faculty of O riental Studies, U niversity of Oxford

2002 The Southern Levant and M aritime Trade During the Middle Bronze Ila Period, 241-263, in: E.D. O ReN and S. Ahituv (ed.), Aharon Kempinski M emorial Volume: Studies in Archaeology and Related Disciplines, Beer-Sheva.

2003 Dating the Early Middle Bronze Age in the Southern Levant: A Preliminary Comparison of Radiocarbon and Archaeo-Historical Synchronizations, 95-110, in: M. BIETAK (ed.) 2003. 
2007 Amenemhet II and the Sea: Maritime Aspects of the Mit Rahina (Memphis) Inscription, E\& L 17: 137-190.

Marcus, E.S., Porath, Y. and Paley, S.M.

2008 The Early Middle Bronze Age Ila Phases at Tel Ifshar and Their External Relations, E\& L 18, 221-244.

MONTET, P.

1928 Byblos et l'Egypte. Quatre Campagnes de Fouilles a Gebeil. 1921-1922-1923-1924, H aut Commissariat de la République Française en Syrie et au Liban. Service des Antiquités et des Beaux Arts, Bibliothèque Archéologique et $\mathrm{H}$ istorique 11 , Paris.

Nordström, H.Å. and Bourriau, J.

1993 Fascicle 2: Ceramic Technology and Fabrics, in: J. Bourriau und Do. ARnold (eds.), An Introduction to Ancient Egyptian Pottery, SDAIK 17, Mainz.

PALEY, S.M. and Porath, Y.

1993 Tel Hefer, 609-614, in: E. Stern, A. LeWinsonGILBOA and J. Aviram (eds.), NEAH L 2, Jerusalem.

1997 Early Middle Bronze Age IIA Remains at Tell el Ifshar, I srael: A Preliminary Report, 369-378, in: E.D. Oren (ed.), The Hyksos: $\mathrm{New} H$ istorical and Archaeological Perspectives, University Museum Monograph 96, Philadel phia.

Paley, S.M., Porath, Y. and Stieglitz, R. R.

1982 The CEmeq Hefer Archaeological Research Project, 1982, IEJ 32:259-261.

1983 The CEmeq Hefer Archaeological Research Project, 1983, IEJ 33:264-266.

VON PILGRIM, C.

1996 Elephantine XVIII. Untersuchungen in der Stadt des M ittleren Reiches und der Zweiten Zwischenzeit, AV 91, Mainz.

Posener, G.

1971 Syria and Palestine: Relations with Egypt, 532-558, in: EDWARDS, I.E.S., GADD C.J., and H AMMOND, N.G.L. (eds.), Early H istory of theM iddleEast. Vol. 1, part 2 of The Cambridge Ancient $\mathrm{H}$ istory, Cambridge.

QUIBELL, J.E.

1898 El Kab, Egypt Research Account 1897, London.

RZEUSKA, T.

1999 Zur Keramik des Mittleren Reichs, in: W. KAISER et al., Stadt und Tempel von Elephantine. 25./ 26./ 27. Grabungsbericht, M DAIK 55:195-204.

SCHIEstl, R. and Seiler, A.

forthc. The Egyptian M iddle Kingdom Pottery $\mathrm{H}$ andbook, Vol- ume 1: The Corpus Volume, Volume2: The Regional Volume, CChEM, Vienna.

Seiler, A.

2005 Tradition und Wandel. DieK eramik als Spiegel der Kulturentwicklung Thebens in der Zweiten Zwischenzeit, SDAIK 32, Mainz.

SHAW, I.

2000 Khafra's quarries in the Sahara, Egyptian Archaeology 16:28-30.

Shaw, I., Bloxam, E., Bunbury, J., Lee, R., Graham, A. and DARNELL, D.

2001 Survey and excavation at the Gebel el-Asr gneiss and quartz quarries in Lower Nubia (1997-2000), Antiquity 75:33-34.

SMITH, S.T.

forthc. Pottery from Askut and the Nubian Forts, in: R. SCHIESTL and A. SeILer (eds), The Egyptian Middle Kingdom Pottery Handbook, Volume 2: Regional Corpus Volume, CChEM, Vienna.

StAGER, L.E.

2001 Port Power in the Early and Middle Bronze Age: The O rganization of $\mathrm{M}$ aritime Trade and $\mathrm{H}$ interland Production, 625-638, in: S.R. WoLfF (ed.), Studies in the Archaeology of Israel and Neighboring Lands in M emory of Douglas L. Esse, SAOC 5, Chicago.

2002 The MB IIA Ceramic Sequence at Tel Ashkelon and I ts Implications for the "Port Power" M odel of Trade, 353-362, in: M. BietaK (ed.) 2002.

2008 Tel Ashkelon, 1578-1586, in: E. Stern, H. GeVA, A. PARIS, and J. Aviram (eds.), NEAHL 5 (Supplementary volume), Jerusalem-Washington, D.C.

TUFNELL, 0 .

1969 The pottery from the Royal Tombs I-III at Byblos, Berytus 17:5-33.

WARD, W.A.

1961 Egypt and the East Mediterranean in the Early Second Millennium B.C., Orientalia 30:22-45, 129-55.

WEGNER, J.

2007 The M ortuary Temple of Sen wosret III at Abydos, Publications of the Pennsylvania-Yale-Institute of Fine Arts/ NYU Expedition to Egypt 8, New Haven and Philadelphia.

Weinstein, J. M.

1975 Egyptian Relations with Palestine in the Middle Kingdom, BASOR 217:1-16.

1992 The Chronology of Palestine in the Early Second Millennium B.C.E., BASOR 288:27-46. 